\title{
Varietal Response to Groundnut Rosette Disease and the First Report of Groundnut ringspot virus in Ghana
}

Andrew S. Appiah, Tasmanian Institute of Agriculture, School of Land and Food, University of Tasmania, New Town, Tasmania 7008, Australia; and Biotechnology and Nuclear Agriculture Research Institute, Ghana Atomic Energy Commission, Legon, Accra, Ghana; Samuel K. Offei, Biotechnology Centre, College of Basic and Applied Sciences, University of Ghana, Legon, Accra, Ghana; and Robert S. Tegg and Calum R. Wilson, Tasmanian Institute of Agriculture, School of Land and Food, University of Tasmania, New Town

\begin{abstract}
Appiah, A. S., Offei, S. K., Tegg, R. S., and Wilson, C. R. 2016. Varietal response to groundnut rosette disease and the first report of Groundnut ringspot virus in Ghana. Plant Dis. 100:946-952.

Twelve cultivars of groundnut were screened in field trials for resistance to groundnut rosette disease (GRD), caused by coinfection with Groundnut rosette assistor virus (GRAV), Groundnut rosette virus (GRV), and its satellite RNA in the coastal savannah of Ghana. 'Oboshie' groundnut was rated as highly resistant; 'Bremaowuo', 'Nkatefufuo', and 'Behenase' as resistant; and 'Nkosuor', 'Kumawu', and 'Otuhia' as moderately resistant. GRAV infection rates of 11.8 to $61.8 \%$ (dry season) and 13.9 to $100 \%$ (wet season) were found, which included symptomless plants, suggesting that some lacked coinfection with GRV and its satellite. Chlorotic ringspot and linepattern symptoms were observed, suggesting infection with Groundnut

ringspot virus (GRSV). Virus identity was confirmed by enzyme-linked immunosorbent assay, reverse-transcription polymerase chain reaction, and amplicon sequencing. This is the first report of GRSV in Ghana. GRSV infection rates were 0.0 to $69.5 \%$ (dry season) and 26.1 to $69.5 \%$ (wet season). Mixed infections of GRAV and GRSV were common in all cultivars except Nkosuor and Bremaowuo in the dry season. Most cultivars graft inoculated with GRD showed significantly reduced height, leaf area, chlorophyll content, dry haulm weight, and seed yield compared with healthy plants. The sources of resistance to GRD and possibly GRAV and GRSV identified in this study could be exploited in groundnut breeding programs.
\end{abstract}

Groundnut rosette disease (GRD) is caused by coinfection of groundnut with Groundnut rosette assistor virus (GRAV), Groundnut rosette virus (GRV), and a satellite RNA of GRV and is a major disease of groundnut (peanut) in Africa, responsible for annual losses in excess of U.S. $\$ 150$ million (Waliyar et al. 2007). Disease expression requires the presence of GRV and its satellite RNA, with both reliant on GRAV for natural vector spread. GRAV alone results in symptomless infection in peanut (Naidu et al. 1999b). The viral pathogens are transmitted by the cowpea or groundnut aphid Aphis craccivora Koch (Okusanya and Watson 1966). GRD presents itself in two major symptom forms-a green rosette and a chlorotic rosette (Gibbons 1977, Murant and Kumar 1990)_although a mosaic rosette has also been reported (Storey and Ryland 1957). The major countries of disease occurrence include Burkina Faso, Ghana, Nigeria, Malawi, Mozambique, and Uganda (Olorunju et al. 2001). Other countries where the disease has been reported are Angola, Côte d'Ivoire, Gambia, Kenya, Madagascar, Niger, Senegal, South Africa, Sudan, Swaziland, Tanzania, and Zaire (Gibbons 1977, Naidu et al. 1999a).

GRD outbreaks are sporadic and unpredictable but can result in complete crop loss (Subrahmanyam et al. 1997). The African groundnut crop has been on the decline over the last three decades as a result of GRD (Ntare and Olorunju 2001). Recurring epidemics of the disease have hampered production and expansion of the crop and greatly altered cropping patterns in several sub-Saharan African countries (Naidu et al. 1998). An epidemic of the GRD in northern Nigeria in 1975 resulted in the destruction of approximately 0.75 million ha of groundnut (Yayock et al. 1976). A similar epidemic in eastern Zambia in 1995 affected approximately 43,000 ha of groundnut and, in 1996, groundnut production was reduced by $23 \%$ in the central region of Malawi as a result of GRD (Anon. 1996). The average

Corresponding author: C. R. Wilson; E-mail: Calum.Wilson@utas.edu.au

Accepted for publication 27 November 2015.

http://dx.doi.org/10.1094/PDIS-07-15-0838-RE

C 2016 The American Phytopathological Society yields of 500 to $800 \mathrm{~kg} / \mathrm{ha}$ reported by farmers in Ghana are far below the potential yields of 1,800 to $2,800 \mathrm{~kg} / \mathrm{ha}$ (Adu-Dapaah et al. 2004). This is at least partially due to viral diseases, including GRD, which is not adequately managed due to high cost and unavailability of insecticides to control the insect vectors.

Tospoviruses occur worldwide (Pappu et al. 2009) and notable among them is Groundnut ringspot virus (GRSV), which is regarded as an emerging threat to crop production in several important crops, including groundnut. The virus was first identified in groundnut from South Africa (de Ávila et al. 1993) and has been subsequently found in soybean in South Africa (Pietersen and Morris 2002); groundnut, tomato, sweet pepper, cocona, coriander, cucumber, and watermelon in Brazil (Boari et al. 2002; Carmelo-García et al. 2014; Leão et al. 2014; Spadotti et al. 2014), groundnut in Argentina (de Breuil et al. 2007); and tomato in Florida (Webster et al. 2010), this later virus being a recombinant between GRSV and Tomato chlorotic spot virus (Webster et al. 2015). GRSV is not seedborne and is naturally vectored by several species of thrips from the genus Franklinella (Pappu et al. 2009).

The devastating nature of GRD has necessitated the use of resistant varieties as the most economical and practical disease control solution. Sources of resistance to GRD in groundnut were first discovered in 1952 in landraces of the late-maturing Virginia groundnut (Arachis hypogaea L. subsp. hypogaea var. hypogaea) from Burkina Faso and Cote d'Ivoire (Catherinet et al. 1954) and has since formed the basis for breeding programs throughout Africa (Olorunju et al. 2001). This resistance was found to be controlled by two recessive genes and was effective against GRV and its satellite RNA (Bock et al. 1990). However, under heavy disease pressure, resistant plants succumb to infection (Wynne et al. 1991). Resistance to GRAV has been identified (Chiyembekeza et al. 1997) with all known GRD-resistant genotypes susceptible to this virus (Subrahmanyam et al. 1998). Resistance to the aphid vector has been found in some groundnut breeding lines (Herselman et al. 2004), with these genotypes shown to be susceptible to GRAV, GRV, and its satellite RNA (Minja et al. 1999). This present study sought to test the resistance of locally grown Ghanaian groundnut cultivars to GRD in order to provide cultivars for disease management in the field and to provide groundnut breeders with robust resistant parent genotypes. 
It has also identified GRSV for the first time in Ghana, and this necessitates consideration of this virus in future breeding programs.

\section{Materials and Methods}

Study site. Field trials were conducted in 2013 (dry season: November to February) and 2014 (wet season: June to September) at the Biotechnology and Nuclear Agriculture Research Institute, Accra, Ghana. The study site was located about $20 \mathrm{~km}$ north of Accra $\left(05^{\circ} 40^{\prime} 60^{\prime \prime} \mathrm{N}\right.$ and $\left.0^{\circ} 13^{\prime} 0^{\prime \prime} \mathrm{W}\right)$, with an elevation of $76 \mathrm{~m}$ above sea level. The area is characterized as coastal savannah with a bimodal rainfall pattern, having a major wet season between the months of March and June and a minor wet season around October to November each year. The mean annual rainfall is $810 \mathrm{~mm}$ distributed over less than 80 days. Temperatures are moderate, with maximums rarely exceeding $32^{\circ} \mathrm{C}$ while the minimums do not fall below $17^{\circ} \mathrm{C}$.

Groundnut cultivars. The planting material consisted of 12 cultivars obtained from the Crop Research Institute of the Council for Scientific and Industrial Research (CSIR), Fumesua, Kumasi. These were six improved cultivars, 'Nkosuor' (M578-79), 'Jenkaar' (MDR-8-19), and 'Azivivi' (RMP12), previously rated as moderately resistant to GRD (Kabbia 2013; Tengey et al. 2013); 'Oboshie' (ICGV 98412), 'Obolo' (ICGV 97049), and 'Otuhia' (ICGV 88709), previously rated as resistant (Kabbia 2013; Owusu-Akyaw et al. 2014; Tengey et al. 2013); five local cultivars ('Kumawu', 'Bremaowuo', 'Nkatefufuo', 'Behenase', and 'Sinkapoporigo'), whose resistance was unknown; and 'Yenyawoso' (ICG(x)SM87057), a susceptible variety.

Trial design. The cultivars were assigned to plots in a randomized complete block design with four replications. In all, 30 seeds (six rows of 5 seeds) of each cultivar were planted per plot, with two rows left vacant for establishing infector rows; there was a planting distance of 25 and $50 \mathrm{~cm}$ within and between plants, respectively. A basal dose of single superphosphate fertilizer was applied to the soil before planting at $40 \mathrm{~kg} \mathrm{ha}^{-1}$. Seed were hand sown during the second week of November for the dry-season trial and the third week of June for the wet-season trial. GRD inoculum was introduced by planting infector rows (Bock and Nigam 1988). Seed of a susceptible local cultivar of groundnut (popularly known as 'Shitaochi' or 'Chinese') were planted in polythene bags and grafted with a field-affected GRD scion at 2 weeks after emergence. These were grown in an insect-proof house, monitored for symptom development, and then transferred to the field, establishing one row of five infector plants between two rows of test plants. Subsequent GRD spread from the infector plants to the genotypes was through natural infection by the Aphis craccivora vector. Presence of this vector species within the trial was confirmed by taxonomic identification of sampled individuals. No insecticide was used throughout the growth of the plants.

Estimation of disease incidence and cultivar rating. Disease incidence data (percentage of plants within each cultivar with visual presence of GRD symptoms) was determined by visual assessment
10 weeks after exposure to sources of inoculum, and a cultivar resistance rating was determined based on a previously described scale (Waliyar et al. 2007) using the percentage of diseased plants, where $<10 \%=$ highly resistant, 11 to $30 \%=$ resistant, 31 to $50 \%=$ moderately resistant, and $>50 \%=$ susceptible.

Serological detection of viruses. Following disease assessment, a three-leaf sample from the top, middle, and bottom of each plant was taken and tested for the presence of GRAV using tripleantibody sandwich enzyme-linked immunosorbent assay (ELISA) (Rajeshwari et al. 1987). Expression of chlorotic ringspots and line patterns suggested the presence of GRSV, which was subsequently included in tests. GRSV was tested by double-antibody sandwich ELISA using antibodies obtained from DSMZ (Braunschweig, Germany) according to the manufacturer's protocol, except that the wash buffer contained $2 \%$ skimmed milk powder to minimize nonspecific binding and reduce the background color. Leaf samples were bulked in groups of five and sap extracted by grinding $1 \mathrm{~g}$ of tissue in $10 \mathrm{ml}$ of extraction buffer containing $20 \mathrm{~g}$ of polyvinylpyrrolidone, $2 \mathrm{~g}$ of ovalbumin, $1.3 \mathrm{~g}$ of anhydrous sodium sulfite, $0.5 \mathrm{ml}$ of Tween-20, $20.8 \mathrm{~g}$ of sodium chloride, $0.2 \mathrm{~g}$ of potassium dihydrogen orthophosphate, $1.15 \mathrm{~g}$ of disodium hydrogen orthophosphate, and $0.2 \mathrm{~g}$ of potassium chloride. Sap extracts from known GRD-infected and healthy plants were used as positive and negative controls, respectively. Absorbance values were measured at $405 \mathrm{~nm}$ using a spectrophotometer (Multiskan Ascent VI.25, version 1.3.1; Flow Laboratories, Helsinki, Finland). Samples with absorbance values more than twice that of the healthy controls were considered positive for the virus. The proportion of plants infected in

Table 1. Groundnut rosette disease incidence and resistance rating of 12 groundnut cultivars based on visual symptoms

\begin{tabular}{lccl}
\hline & \multicolumn{2}{c}{ Disease incidence $(\%)$} & \\
\cline { 2 - 3 } Cultivar & Dry season & Wet season & Resistance ratingz \\
\hline Bremaowuo & 15.3 & 25.7 & Resistant \\
Sinkapoporigo & 46.4 & 60.9 & Susceptible \\
Oboshie & 5.4 & 7.3 & Highly resistant \\
Obolo & 49.1 & 55.9 & Susceptible \\
Kumawu & 18.8 & 41.1 & Moderately resistant \\
Jenkaar & 7.8 & 59.8 & Susceptible \\
Nkosuor & 5.5 & 37.2 & Moderately resistant \\
Nkatefufuo & 16.0 & 28.8 & Resistant \\
Azivivi & 11.1 & 60.0 & Susceptible \\
Behenase & 12.8 & 24.5 & Resistant \\
Otuhia (Resistant) & 10.3 & 37.5 & Moderately resistant \\
Yenyawoso (Susceptible) & 22.5 & 53.1 & Susceptible \\
\hline
\end{tabular}

Ratings based on wet-season trial: highly resistant $(<10 \%)$, resistant (11 to $30 \%)$, moderately resistant (31 to $50 \%)$, and susceptible (>50\%).

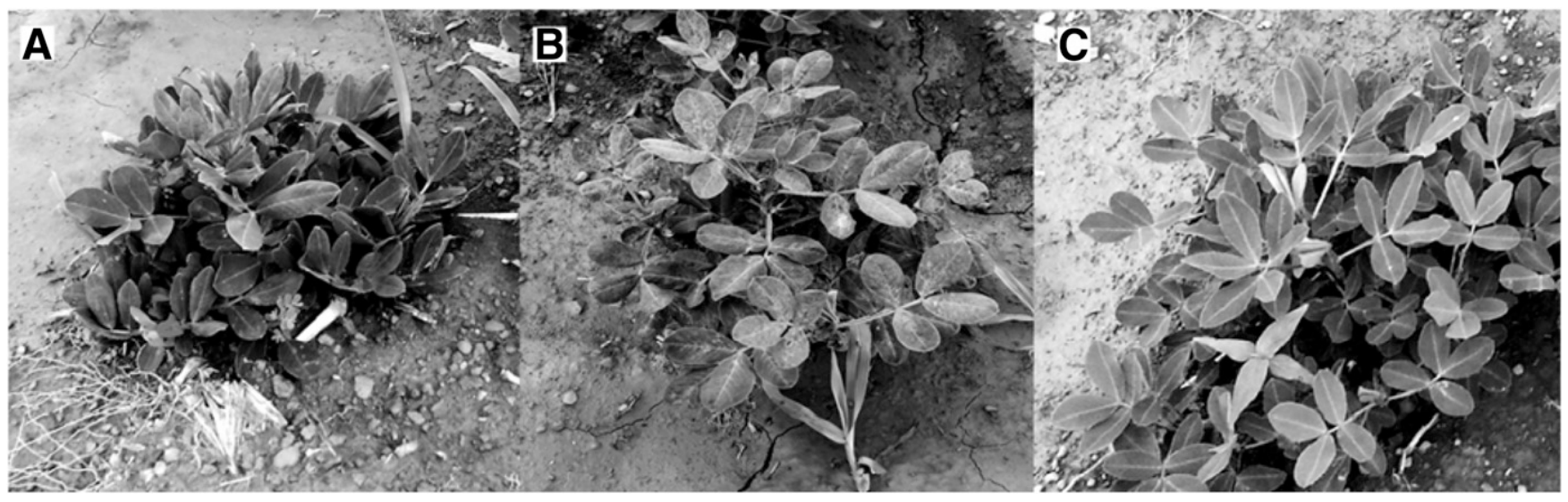

Fig. 1. Diseased Sinkapoporigo groundnut plants within the field 8 weeks after exposure to sources of inoculum. A, Green rosette symptoms of groundnut rosette disease; B, chlorotic ringspots, leaf deformation, and line pattern symptoms of Groundnut ringspot virus infection; and C, healthy plant. 
bulked samples was calculated using the likelihood estimator method (Gibbs and Gower 1960).

RNA isolation, reverse-transcription polymerase chain reaction, and sequencing of the GRSV nucleocapsid gene. Total RNA was extracted from symptomatic leaf samples using the PowerPlant RNA isolation kit with DNase (Mo Bio Laboratories Inc., Carlsbad, CA), according to the manufacturer's instructions. cDNA was synthesized from the total RNA using the iScript Reverse Transcription Supermix (Bio-Rad, Hercules, CA) and PCR was carried out using the primer pair NGRSVR (5'-CCCTGCAGAGCTCTCATGCAA CACCAGCAATCTTG- $3^{\prime}$ ), which anneals at the $3^{\prime}$ end of the $N$ gene (capsid protein), and NGRSVF (5'-GATCTAAGGATCCACCATGTC TAAGGTCAAGCTC-3'). PCR conditions used were as described by Boari et al. (2002). The PCR products were purified with QIAquick PCR purification kit (Qiagen GmbH, Hilden, Germany) and sequenced directly in both directions at the Australian Genome Research Facility, Melbourne, Australia.

Effect of GRD on agronomic performance. Seed of the various cultivars were raised in polythene bags in an insect-proof house. Two weeks after emergence, 30 plants of each genotype were grafted with GRD-infected scions (collected from the field) that had tested positive for GRAV and 30 were grafted with healthy GRAV-free scions (obtained from disease-free plants raised in an insect-proof house that tested negative for GRAV) as controls. The plants were maintained in the insect-proof house for 1 week, then transplanted to the field. They were assigned to plots in a randomized complete block design with three replicates. Ten plants per plot were planted at a distance of 25 and $50 \mathrm{~cm}$ within and between plants, respectively. Basal application of $\mathrm{P}_{2} \mathrm{O}_{5}$ at $40 \mathrm{~kg} / \mathrm{ha}$ was applied to the plots. The plants were sprayed at 2-week intervals with the insecticide Actellic 50 EC (active ingredient: pirimiphos-methyl; Syngenta Crop Protection Ag, Basel, Switzerland) to prevent external infection by incoming viruliferous aphids.

The experiment was repeated for four of the cultivars: Sinkapoporigo (resistance unknown), Nkosuor (moderately resistant), Otuhia (resistant), and Yenyawoso (susceptible). The plants were inoculated as described above but, in this instance, plants remained within the insect-proof greenhouse.

Plant measurements. The concentration of chlorophyll in both symptomatic and healthy leaves of each cultivar was determined at four (preflowering) and eight (during pod development) weeks after inoculation using a chlorophyll content meter (CCM-200 Plus; OptiSciences, Hudson, NH). Leaf area of the third topmost fully expanded leaves was measured from both infected and healthy plants of each cultivar 2 weeks before harvest using a leaf area meter (Area
Meter AM 300; ADC Bioscientific Ltd., Herts, UK). Plant height of both infected and healthy plants of each variety was measured from the base of the plant (at soil level) to the tip of the stem. At harvest, diseased and healthy plants were cut at soil level, separated into stems and leaves, and weighed. The samples were placed in paper bags and dried in an oven at $60^{\circ} \mathrm{C}$ for $48 \mathrm{~h}$ and reweighed. The dry haulm weight $(\%)$ was estimated as dry weight/fresh weight $\times 100$. Seed yield was assessed by harvesting pods from each variety from diseased and healthy plants, which were then air dried and shelled. Average seed yield per plant and the 100-seed weight for diseased and healthy plants were then measured for each cultivar.

Data analysis. All data sets were analyzed by one-way analysis of variance (ANOVA) using GENSTAT 9.1 software (VSN International Ltd., Hemel Hempstead, UK) after ensuring an approximate normal distribution for each variable. Where normality was not found, data sets were arcsine transformed prior to analysis. Where ANOVA indicated significant variation between variables $(P<0.05)$, means were separated using the least significant difference test.

\section{Results}

Susceptible cultivars expressed typical GRD symptoms, including shortening of the internodes leading to severe stunting, reduced leaf size, leaf distortion, and mosaic (Fig. 1). Most of the symptoms appeared 3 weeks after exposure to the source of inoculum. Disease spread and severity varied significantly among the cultivars between

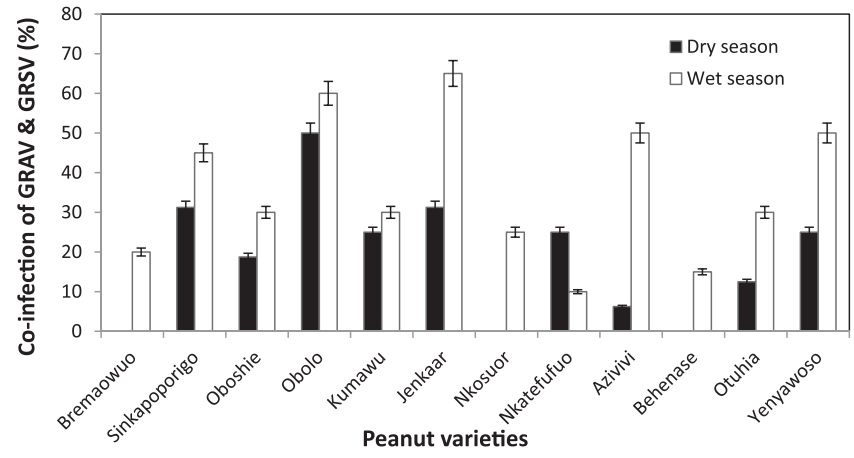

Fig. 2. Extent of coinfection of groundnut cultivars within trial plots with Groundnut rosette assistor virus (GRAV) and Groundnut ringspot virus (GRSV). Plants were tested 10 weeks after exposure to sources of inoculum. Vertical bars indicate standard errors.

Table 2. Infection of 12 groundnut cultivars by Groundnut rosette assistor virus (GRAV) and Groundnut ringspot virus (GRSV)

\begin{tabular}{|c|c|c|c|c|c|}
\hline \multirow[b]{3}{*}{ Cultivar } & \multirow[b]{3}{*}{$N^{\mathbf{z}}$} & \multicolumn{4}{|c|}{ Infection (\%) by ELISA (transformed data) ${ }^{y}$} \\
\hline & & \multicolumn{2}{|c|}{ GRAV } & \multicolumn{2}{|c|}{ GRSV } \\
\hline & & Dry season & Wet season & Dry season & Wet season \\
\hline Bremaowuo & 20 & $13.9 \mathrm{c}$ & $13.9 \mathrm{~d}$ & $19.5(0.21) b$ & 69.5 (1.07) \\
\hline Sinkapoporigo & 20 & $61.8 \mathrm{ab}$ & $75.6 \mathrm{ab}$ & $23.7(0.25) \mathrm{b}$ & $57.3(0.53)$ \\
\hline Oboshie & 20 & $25.0 \mathrm{c}$ & $100 \mathrm{a}$ & $29.2(0.30) \mathrm{b}$ & $45.0(0.81)$ \\
\hline Obolo & 20 & $75.0 \mathrm{a}$ & $87.7 a b$ & $69.5(1.37) \mathrm{a}$ & $63.4(0.92)$ \\
\hline Kumawu & 20 & $21.6 \mathrm{c}$ & $32.8 \mathrm{~cd}$ & $36.8(0.51) \mathrm{b}$ & $69.5(0.66)$ \\
\hline Jenkaar & 20 & $34.4 \mathrm{bc}$ & $100 \mathrm{a}$ & $29.2(0.31) \mathrm{b}$ & $57.3(1.21)$ \\
\hline Nkosuor & 20 & $11.8 \mathrm{c}$ & $87.8 \mathrm{ab}$ & $0.0(0.00) \mathrm{b}$ & $26.1(0.66)$ \\
\hline Nkatefufuo & 20 & $27.1 \mathrm{c}$ & $20.0 \mathrm{~d}$ & $31.3(0.33) \mathrm{b}$ & $32.3(0.15)$ \\
\hline Azivivi & 20 & $13.9 \mathrm{c}$ & $93.8 \mathrm{a}$ & $6.3(0.06) \mathrm{b}$ & $45.0(0.42)$ \\
\hline Behenase & 20 & $36.8 \mathrm{bc}$ & $20.0 \mathrm{~d}$ & $8.4(0.08) b$ & $63.4(1.01)$ \\
\hline Otuhia (resistant) & 20 & $13.9 \mathrm{c}$ & $81.6 \mathrm{ab}$ & $27.1(0.41) \mathrm{b}$ & $26.1(0.48)$ \\
\hline Yenyawoso (susceptible) & 20 & $19.4 \mathrm{c}$ & $57.2 \mathrm{bc}$ & $29.2(0.31) \mathrm{b}$ & $69.5(0.73)$ \\
\hline$P$ value & $\ldots$ & $<0.001$ & $<0.001$ & $<0.006$ & ns \\
\hline LSD (0.05) & $\ldots$ & 29.18 & 32.93 & 0.58 & $\ldots$ \\
\hline
\end{tabular}

y Infection data sets were analyzed for normality. ELISA = enzyme-linked immunosorbent assay. Where required (GRSV data sets), data were arcsine transformed prior to statistical analysis. Values in the columns followed by the same letter are not significantly different $(P>0.05)$ from each other according to the least significant difference $(\mathrm{LSD})$ test; $\mathrm{ns}=$ not significant.

z Number of plants tested. 
the wet- and dry-season trials, with susceptible genotypes showing more severe symptoms in the wet season. Some plants expressed additional virus-like symptoms, including chlorotic ringspots, line patterns, and deformation of leaflets, indicative of GRSV infection (Fig. 1). These symptoms could clearly be distinguished from those resulting from GRD.

Disease incidence and cultivar rating to GRD. The percentage of diseased plants (Table 1) varied significantly within and between seasons among the groundnut cultivars, with disease incidence higher in the wet than the dry seasons. The highest disease incidence in the dry season was found in Obolo (49.1\%), while Sinkapoporigo $(60.9 \%)$ had the highest in the wet season. Oboshie had the lowest proportion of diseased plants in both the dry $(5.42 \%)$ and wet $(7.30 \%)$ seasons. Cultivars were rated for resistance based on wetseason results, which provided the greatest disease pressure. Oboshie $(7.3 \%)$ rated highly resistant; Bremaowuo (25.7\%), Nkatefufuo (28.8\%), and Behenase (24.5\%) were considered resistant; Nkosuor (37.2\%), Kumawu (41.1\%), and Otuhia $(37.5 \%)$ were moderately resistant; and Sinkapoporigo (60.9\%), Obolo (55.9\%), Jenkaar $(59.8 \%)$, Azivivi $(60.0 \%)$, and Yenyawoso $(53.1 \%)$ were rated susceptible. With the exception of Oboshie, Nkosuor, and Otuhia, all the improved cultivars with putative resistance to GRD succumbed to the disease.

Serological detection of viruses. Significant differences between cultivars in incidence of GRAV and GRSV were found in both the dry and wet season (Table 2). The proportions of infected plants for both viruses were generally lower in the dry than the wet season. In the dry season, accession Obolo had the greatest GRAV infection (75\%) while the least infection was recorded in Nkosuor (11.8\%). In the wet season, all plants of Oboshie and Jenkaar succumbed to infection with GRAV while the least infection occurred in Bremaowuo $(13.9 \%)$. A relatively low detection of GRAV was found in Bremaowuo (13.9\%), Nkatefufuo (27.1\%), Kumawu (32.8\%), and Behenase (36.8\%). Oboshie (25\%), Nkosuor (11.8\%), and Azivivi (13.9\%), as well as Otuhia (resistant control), had low numbers of infected plants in the dry season but infection was high in the wet season.

Table 3. Effect of groundnut rosette disease on plant height, leaf area, chlorophyll content, haulm dry weight, and yield of groundnut cultivars

\begin{tabular}{|c|c|c|c|c|c|c|c|c|}
\hline \multirow[b]{2}{*}{ Trial, cultivar ${ }^{\mathrm{t}}$} & \multirow[b]{2}{*}{ Health $^{\mathrm{u}}$} & \multirow[b]{2}{*}{ Height $(\mathbf{c m})^{\mathrm{v}}$} & \multirow[b]{2}{*}{$\operatorname{Area}\left(\mathrm{cm}^{2}\right)^{\mathrm{w}}$} & \multicolumn{2}{|c|}{ Chlorophyll contents } & \multirow[b]{2}{*}{ Haulm $(\%)^{x}$} & \multirow[b]{2}{*}{$100-$ Seed $(g)^{y}$} & \multirow[b]{2}{*}{ Yield $(\mathrm{g})^{\mathrm{z}}$} \\
\hline & & & & Preflowering & $\overline{\text { Development }}$ & & & \\
\hline \multicolumn{9}{|l|}{ 1: Field } \\
\hline \multirow{2}{*}{ Bremaowuo } & $\mathrm{D}$ & $10.2 \mathrm{jk}$ & $3.51 \mathrm{jhij}$ & 13.4 efghi & $13.4 \mathrm{ijkl}$ & $32.4 \mathrm{hi}$ & $25.3 \mathrm{kl}$ & $7.8 \mathrm{fg}$ \\
\hline & $\mathrm{H}$ & 15.8 cdefghij & $7.23 \mathrm{abc}$ & $20.9 \mathrm{abcd}$ & $25.8 \mathrm{cdef}$ & $35.0 \mathrm{def}$ & $28.5 \mathrm{ijk}$ & $21.8 \mathrm{ef}$ \\
\hline \multirow[t]{2}{*}{ Sinkapoporigo } & $\mathrm{D}$ & 15.4 cdefghijk & $1.88 \mathrm{j}$ & 12.5 fghi & 27.7 cdef & $28.7 \mathrm{k}$ & $27.2 \mathrm{jk}$ & $9.4 \mathrm{fg}$ \\
\hline & $\mathrm{H}$ & $23.9 \mathrm{ab}$ & 4.11 efghi & $24.9 \mathrm{ab}$ & $33.8 \mathrm{abcd}$ & $37.0 \mathrm{bc}$ & $34.2 \mathrm{defg}$ & $46.3 \mathrm{abcd}$ \\
\hline \multirow[t]{2}{*}{ Oboshie } & $\mathrm{D}$ & $8.7 \mathrm{k}$ & $2.33 \mathrm{ij}$ & $12.0 \mathrm{ghi}$ & 13.9 hijkl & $37.2 \mathrm{~b}$ & $20.3 \mathrm{~m}$ & $5.7 \mathrm{~g}$ \\
\hline & $\mathrm{H}$ & $24.9 \mathrm{a}$ & $7.40 \mathrm{abc}$ & $26.8 \mathrm{a}$ & $40.6 \mathrm{ab}$ & $40.9 \mathrm{a}$ & $46.1 \mathrm{ab}$ & $49.0 \mathrm{abcd}$ \\
\hline \multirow[t]{2}{*}{ Obolo } & $\mathrm{D}$ & $9.4 \mathrm{jk}$ & $2.52 \mathrm{ij}$ & 14.6 defgh & 23.4 efghi & $28.9 \mathrm{k}$ & $34.4 \mathrm{def}$ & $13.3 \mathrm{fg}$ \\
\hline & $\mathrm{H}$ & $24.3 \mathrm{ab}$ & $6.94 \mathrm{abc}$ & $26.6 \mathrm{a}$ & 31.6 bcde & $40.6 \mathrm{a}$ & $47.1 \mathrm{a}$ & $56.3 \mathrm{abc}$ \\
\hline \multirow[t]{2}{*}{ Kumawu } & $\mathrm{D}$ & 18.2 abcdefgh & $4.94 \mathrm{defg}$ & $10.9 \mathrm{hi}$ & $12.9 \mathrm{jkl}$ & 33.7 efgh & 30.6 ghij & $11.4 \mathrm{fg}$ \\
\hline & $\mathrm{H}$ & $22.3 \mathrm{abc}$ & $8.66 \mathrm{a}$ & 17.9 cdefg & 24.1 defgh & 35.3 cde & $36.9 \mathrm{~cd}$ & $55.2 \mathrm{abc}$ \\
\hline \multirow[t]{2}{*}{ Jenkaar } & $\mathrm{D}$ & 12.4 ghijk & 3.23 ghij & 15.8 defgh & 22.9 efghij & 33.4 efgh & 32.3 efgh & $7.8 \mathrm{fg}$ \\
\hline & $\mathrm{H}$ & 20.2 abcde & $5.04 \mathrm{defg}$ & $24.8 \mathrm{abc}$ & $35.4 \mathrm{abc}$ & $36.2 \mathrm{bcd}$ & $36.3 \mathrm{~cd}$ & $33.7 \mathrm{de}$ \\
\hline \multirow[t]{2}{*}{ Nkosuor } & $\mathrm{D}$ & 13.4 efghijk & $3.03 \mathrm{hij}$ & $10.4 \mathrm{hi}$ & 21.1 fghijk & $29.8 \mathrm{jk}$ & $22.5 \mathrm{~lm}$ & $6.0 \mathrm{~g}$ \\
\hline & $\mathrm{H}$ & 20.2 abcde & $5.76 \mathrm{cdef}$ & $21.1 \mathrm{abcd}$ & $28.0 \mathrm{cdef}$ & 33.7 efgh & 35.1 cde & $43.7 \mathrm{bcd}$ \\
\hline \multirow[t]{2}{*}{ Nkatefufuo } & $\mathrm{D}$ & 14.4 defghijk & 4.06 fghi & $9.0 \mathrm{hi}$ & 10.51 & $33.1 \mathrm{fgh}$ & $42.6 \mathrm{~b}$ & $10.5 \mathrm{fg}$ \\
\hline & $\mathrm{H}$ & 20.8 abcd & $7.23 \mathrm{abc}$ & $19.0 \mathrm{bcdef}$ & 23.6 defghi & $34.8 \mathrm{defg}$ & $46.4 \mathrm{a}$ & $47.5 \mathrm{abcd}$ \\
\hline \multirow{2}{*}{ Azivivi } & $\mathrm{D}$ & 11.9 hijk & $3.03 \mathrm{hij}$ & $10.1 \mathrm{hi}$ & 10.11 & $32.9 \mathrm{ghi}$ & $29.1 \mathrm{hij}$ & $11.0 \mathrm{fg}$ \\
\hline & $\mathrm{H}$ & 19.8 abcdef & 5.74 cdef & $22.9 \mathrm{abc}$ & 25.5 cdefg & 35.3 cde & $38.4 \mathrm{c}$ & $55.4 \mathrm{abc}$ \\
\hline \multirow[t]{2}{*}{ Behenase } & $\mathrm{D}$ & 14.5 defghijk & 3.98 fghi & $10.5 \mathrm{hi}$ & $11.3 \mathrm{kl}$ & $31.0 \mathrm{ij}$ & 30.9 fghi & $5.5 \mathrm{~g}$ \\
\hline & $\mathrm{H}$ & 19.2 abcdefg & $7.77 \mathrm{ab}$ & 19.5 bcde & 22.9 efghij & 33.4 efgh & 34.9 cde & $41.0 \mathrm{~cd}$ \\
\hline \multirow[t]{2}{*}{ Otuhia (R) } & $\mathrm{D}$ & 12.8 fghijk & $2.69 \mathrm{hij}$ & $6.5 \mathrm{i}$ & 15.3 ghijkl & $34.6 \mathrm{defg}$ & $32.4 \mathrm{efgh}$ & $11.0 \mathrm{fg}$ \\
\hline & $\mathrm{H}$ & $22.9 \mathrm{ab}$ & 5.89 cde & $24.2 \mathrm{abc}$ & $42.6 \mathrm{a}$ & $36.3 \mathrm{bcd}$ & $43.8 \mathrm{ab}$ & $58.8 \mathrm{ab}$ \\
\hline \multirow[t]{2}{*}{ Yenyawoso (S) } & $\mathrm{D}$ & $11.0 \mathrm{ijk}$ & 4.41 defgh & $11.8 \mathrm{ghi}$ & 8.81 & $35.3 \mathrm{cde}$ & $34.5 \mathrm{def}$ & $13.4 \mathrm{fg}$ \\
\hline & $\mathrm{H}$ & 17.4 bcdefghi & $5.99 \mathrm{bcd}$ & 20.1 abcde & $29.3 \mathrm{cdef}$ & $37.4 \mathrm{~b}$ & $34.9 \mathrm{cde}$ & $61.7 \mathrm{a}$ \\
\hline$P$ value & $\ldots$ & $<0.001$ & $<0.001$ & $<0.001$ & $<0.001$ & $<0.001$ & $<0.001$ & $<0.001$ \\
\hline LSD (0.05) & $\begin{array}{l}\cdots \\
\cdots\end{array}$ & 7.08 & 1.822 & 6.95 & 10.35 & 1.94 & 3.69 & 15.72 \\
\hline \multicolumn{9}{|l|}{ 2: Greenhouse } \\
\hline \multirow[t]{2}{*}{ Sinkapoporigo } & $\mathrm{D}$ & $29.4 \mathrm{a}$ & $3.3 \mathrm{~d}$ & $12.8 \mathrm{bc}$ & $6.5 \mathrm{~d}$ & $23.3 \mathrm{c}$ & $27.8 \mathrm{~d}$ & $9.2 \mathrm{c}$ \\
\hline & $\mathrm{H}$ & $46.9 \mathrm{c}$ & $8.2 \mathrm{c}$ & $25.4 \mathrm{a}$ & $21.6 \mathrm{ab}$ & $26.7 \mathrm{abc}$ & $43.3 \mathrm{ab}$ & $44.8 \mathrm{a}$ \\
\hline \multirow[t]{2}{*}{ Nkosuor } & $\mathrm{D}$ & $28.3 \mathrm{~cd}$ & $4.1 \mathrm{~d}$ & $11.7 \mathrm{c}$ & $8.6 \mathrm{~cd}$ & $27.6 \mathrm{abc}$ & $19.0 \mathrm{e}$ & $4.8 \mathrm{c}$ \\
\hline & $\mathrm{H}$ & $35.6 \mathrm{~b}$ & $10.1 \mathrm{ab}$ & $25.2 \mathrm{a}$ & $20.6 \mathrm{ab}$ & $28.5 \mathrm{ab}$ & $35.3 \mathrm{c}$ & $35.4 \mathrm{~b}$ \\
\hline Otuhia & $\mathrm{D}$ & $24.1 \mathrm{~d}$ & $4.2 \mathrm{~d}$ & $15.3 \mathrm{bc}$ & $8.5 \mathrm{~cd}$ & $24.6 \mathrm{bc}$ & $37.1 \mathrm{c}$ & $10.9 \mathrm{c}$ \\
\hline & $\mathrm{H}$ & $33.1 \mathrm{bc}$ & $11.7 \mathrm{a}$ & $27.9 \mathrm{a}$ & $22.3 \mathrm{a}$ & $29.5 \mathrm{a}$ & $46.2 \mathrm{a}$ & $49.7 \mathrm{a}$ \\
\hline Yenyawoso & $\mathrm{D}$ & $31.8 \mathrm{bc}$ & $9.5 \mathrm{bc}$ & $16.7 \mathrm{~b}$ & $10.2 \mathrm{c}$ & $24.8 \mathrm{abc}$ & $23.0 \mathrm{e}$ & $8.8 \mathrm{c}$ \\
\hline & $\mathrm{H}$ & $36.4 \mathrm{~b}$ & $10.2 \mathrm{ab}$ & $24.3 \mathrm{a}$ & $18.2 \mathrm{~b}$ & $27.8 \mathrm{abc}$ & $39.6 \mathrm{bc}$ & $52.8 \mathrm{a}$ \\
\hline$P$ value & $\ldots$ & $<0.001$ & $<0.001$ & $<0.001$ & $<0.001$ & $<0.001$ & $<0.001$ & $<0.001$ \\
\hline LSD (0.05) & $\ldots$ & 5.24 & 1.90 & 3.99 & 3.44 & 4.78 & 4.56 & 9.42 \\
\hline $\begin{array}{l}\text { Shlorophyll cont } \\
\text { by the same lette } \\
\mathrm{t} \text { R = resistant and } \\
\text { u } D=\text { diseased and } \\
\text { v Plant height mea } \\
{ }^{\mathrm{w}} \text { Leaf area measur } \\
{ }^{\mathrm{x}} \text { Dry weight of ha } \\
\text { y } \text { The } 100 \text {-seed we } \\
\text { z Average yield (g) }\end{array}$ & $\begin{array}{l}\text { taken at } \mathrm{f} \\
\text { re not sign } \\
=\text { susceptil } \\
=\text { healthy } \\
\text { ed from ba } \\
\text { from the } \mathrm{t}\end{array}$ & $\begin{array}{l}\text { of the plant (at } \\
\text { d topmost fully }\end{array}$ & $\begin{array}{l}\text { level) to the tip } \\
\text { anded leaves of }\end{array}$ & $\begin{array}{l}\text { the stem at hat } \\
\text { ch plant } 2 \text { weel }\end{array}$ & $\begin{array}{l}\text { st. } \\
\text { efore harvest. }\end{array}$ & lifference & ues in the $c$ & $\mathrm{~s}$ followed \\
\hline
\end{tabular}


Of particular interest was Oboshie, which had very low levels of disease in both seasons but very high levels of GRAV infection in the wet season.

Serological identity of GRSV was confirmed by reversetranscription (RT)-PCR using GRSV-specific primers. BLAST analysis of sequence data for a 768-bp fragment of the $\mathrm{N}$ gene amplicon (GenBank accession number KT345728) revealed $>94.7 \%$ sequence identity to the range of GRSV isolates present on the GenBank database. The GRSV isolates of closest homology originated from Florida (HQ634665; 98\%) and South Africa (AF487516; 97\%). In the dry season, Obolo had the highest number of GRSV-infected plants $(69.5 \%)$ while Nkosuor did not succumb to infection. In the wet season, there were no significant differences in GRSV infections among the cultivars. Even though GRD symptoms were predominant among the groundnut genotypes, coinfection with GRSV was found in most of the samples (Fig. 2). In the dry season, Sinkapoporigo and Jenkaar had the highest proportion of plants with mixed infection $(31.25 \%)$ while Nkosuor and Behenase had none. However, in the wet season, Jenkaar $(65 \%)$ had the highest percentage of mixed infection while the least was associated with Nkatefufuo (10\%).

Effect of GRD on agronomic performance. Plant height, leaf area, chlorophyll content, dry haulm weight, and seed yield were all reduced by GRD (Table 3 ). The disease retarded growth and resulted in significant reduction $(P<0.001)$ of plant height in Oboshie (65\%), Obolo (61\%), Otuhia (44.2\%), Azivivi (39.69\%), Jenkaar (38.29\%), and Sinkapoporigo (35.6\%) compared with the healthy controls for the field trial. Similarly, plant height was reduced in all cultivars tested in the greenhouse, with Sinkapoporigo showing the greatest reduction. Leaf area was significantly reduced $(P<$ 0.001 ) in all the cultivars except Yenyawoso and Jenkaar for the field trial and Yenyawoso for the greenhouse trial. The greatest reductions were found in Obolo $(63.68 \%)$ and Oboshie $(68.51 \%)$ while the least was found in Kumawu (42.9\%). In the greenhouse, the greatest reduction in leaf area was found in Otuhia (64.1\%) while the least was in Yenyawoso $(6.9 \%)$.

Chlorophyll content was reduced significantly $(P<0.001)$ in infected plants of most cultivars in both field and greenhouse trials. Before flowering, the greatest reduction occurred in Otuhia (73.23\%) and the least was recorded in Bremaowuo (36.07\%) in the field trial while Nkosuor $(53.6 \%)$ and Yenyawoso $(31.3 \%)$ had the greatest and least, respectively, in the greenhouse trial. After flowering, diseased plants of Yenyawoso, Oboshie, Otuhia, and Azivivi had their chlorophyll content significantly reduced by $70.1,65.7,64.2$, and $60.5 \%$, respectively. Chlorophyll was not significantly reduced in diseased Sinkapoporigo, Obolo, and Nkosuor plants during pod development. In the greenhouse, Sinkapoporigo, Otuhia, Nkosuor, and Yenyawoso had their chlorophyll content reduced by $69.9,61.8,58.3$, and $43.9 \%$, respectively.

Dry haulm weight of infected plants was significantly reduced $(P<$ 0.001 ) in all cultivars except Kumawu, Nkatefufuo, and Otuhia, in the field. The highest reductions in haulm weight were observed in Obolo (29.01\%) and Sinkapoporigo (22.5\%). In the greenhouse, haulm weight was reduced in virus-infected plants of all cultivars but the reduction was significant in Otuhia only. Infected plants had numerous pegs, unfulfilled pods, and a few single-seeded pods when compared with healthy plants (Fig. 3). Yield reduction in the field due to GRD was significant $(P<0.001)$ in all cultivars except Bremaowuo and ranged from 73.09 to $88.40 \%$. In the greenhouse, the reduction was significant for all cultivars and ranged from 79.5 to $86.4 \%$. Similarly GRD significantly diminished $(P<0.001)$ 100-seed weights for all field-tested cultivars except Bremaowuo and Yenyawoso but the reduction was significant for all cultivars tested in the greenhouse. Oboshie and Nkosuor showed the greatest reduction in average yield per plant and in 100-seed weight in the field and greenhouse, respectively.

\section{Discussion}

The trials resulted in effective screening of groundnut cultivars for GRD. Susceptible cultivars expressed typical symptoms of the disease, including shortening of the internodes leading to severe stunting, reduced leaf size, leaf distortion, and mosaic (Waliyar et al. 2007). Resistance to GRD was found in four of the local cultivars while resistance was confirmed in three of the improved cultivars.

The relatively harsh environmental conditions associated with the dry season, with lack of rainfall and high temperatures, would have reduced volunteer plants and vector populations and led to the reduced disease incidence observed compared with the wet-season trial. Jenkaar and Azivivi (with putative moderate resistance) and Obolo (with putative resistance) were rated as susceptible to GRD in the wet-season trial, with Obolo also performing poorly in the dry season. The screening method and the viral strains used in studies that first described the resistance of the improved cultivars tested here are not known. GRD-resistant lines are not immune to the virus and individual plants can succumb to the disease under heavy inoculum pressure (Wynne et al. 1991); also, resistance may be overcome by more virulent strains of rosette disease agents, or perhaps compromised by mixed infection with GRSV. It is also possible that a susceptible cultivar may have escaped infection and been erroneously rated as resistant. However, the poor performance of these cultivars suggests that they may not be useful in minimizing GRD in Ghana.

GRAV was detected in all the cultivars at varying concentrations. Infection levels generally reflected GRD expression; however, a number of symptomless plants tested positive for GRAV. This was best exemplified by Oboshie, which had the least number of GRD plants and was rated highly resistant and yet had a very high level of infection with GRAV in the wet-season trial. This may be due to late-season infections which have yet to express symptoms or may reflect infection by GRAV in the absence of GRV and its satellite, which is known to result in symptomless infection (Naidu et al. 1999b). This may reflect a level of resistance to GRV within Oboshie. The relatively low detection of GRAV in genotypes Bremaowuo, Nkatefufuo, Kumawu, and Behenase in both seasons suggests some level of resistance to either GRAV or its aphid vector. Resistance to $A$. craccivora has been identified in some groundnut breeding lines (Herselman et al. 2004) but no GRAV-resistant cultivars have yet been described (Chiyembekeza et al. 1997), and all GRV-resistant germplasm lines and genotypes that have been identified are susceptible to GRAV (Subrahmanyam et al. 1998). Oboshie, Nkosuor, Azivivi, and Otuhia (resistant control) had low proportion of infected plants in the dry season but had high proportions of infected plants in the wet season, due to heavy inoculum pressure resulting from volunteer plants from the previous trial or higher numbers of aphid vectors. The high level of GRAV infection among Obolo and Sinkapoporigo in the dry season is probably due to their extreme susceptibility to the virus.

Like GRAV, GRSV was detected in all the cultivars. However, the absence of infection in the dry season and the low percentage of

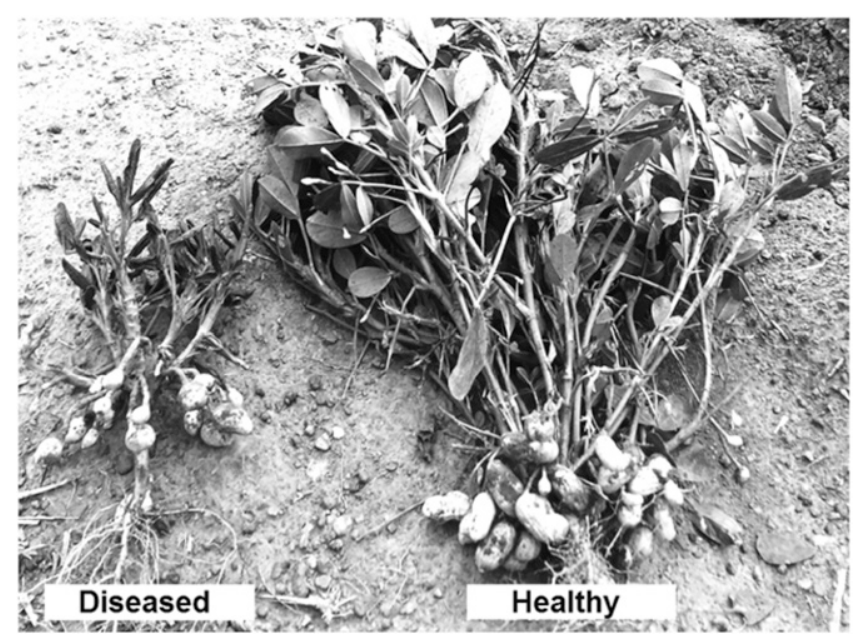

Fig. 3. Example of the effect of groundnut rosette disease on yield of Sinkapoporigo groundnut pods. 
GRSV-infected plants in Nkosuor may suggest some level of resistance to the virus or its thrips vectors. Knowledge of thrips species within Ghana is lacking and further surveys to identify possible vectors of GRSV in Ghanaian groundnut are warranted. The identification of GRSV at such high incidences in addition to GRD agents in the virus disease complex of groundnut in Ghana is of concern, considering the damaging nature and the complex etiology of GRD. Combined losses resulting from GRD and GRSV have the potential to cripple commercial production of groundnut. GRSV is a relatively recently described virus, regarded as an emerging threat to food crop production (Pappu et al. 2009). In most cases, GRSV was found in mixed infection with GRAV, even though GRD symptoms were predominant. It is not clear whether most GRSV symptoms were masked by GRD. It is also not clear whether the extremely severe GRD symptoms observed were as a result of a synergistic effect between GRD agents and GRSV.

GRD is known to dramatically reduce plant height and leaf area in diseased groundnut (Naidu and Kimmins 2007). Notably, in this trial, plant heights were not significantly reduced in Kumawu, Nkatefufuo, Behenase, Bremaowuo, Nkosuor, and Yenyawoso in the field.

Reduction in chlorophyll content of virus-infected plants is commonly reported (Singh and Shukla 2009; Sutha and Rajappan 1998). The reduction in chlorophyll content may be due to the inhibition of chlorophyll synthesis or the breakdown of chloroplast in leaves of infected plants (Wilson 2014). Chlorophyll content was reduced in GRD-affected plants of all varieties tested in the trial before flowering.

Dry haulm weight, 100-seed weight, and average yield per plant were significantly reduced in diseased plants of most varieties. The reductions may be attributed to the reduced photosynthetic efficiencies (Funayama et al. 1997). Reduction in dry weight of virusinfected groundnut and other plants (Naidu and Kimmins 2007; Wilson 2014) has been widely reported. Numerous pegs, unfulfilled pods, and a few single-seeded pods on GRD-affected plants have also been previously reported (Olorunju et al. 1991). Complete losses in pod yield can result if infection occurs before flowering (Naidu et al. 1999a). Reduction in yield as a result of GRAV infection has also been reported (Naidu and Kimmins 2007).

This study has identified resistance to GRD in four of the locally used Ghanaian groundnut cultivars under field conditions. While three of the six improved varieties maintained their resistance, others succumbed to the disease. The resistant genotypes found among the local varieties could be used together with other improved varieties in the interim management of the disease in the field by farmers and further exploited in breeding programs for the development of virusresistant varieties. However, it is imperative to ascertain whether the resistance observed is related to the virus or the vector.

The study provides the first report of GRSV in groundnut in Ghana, which had hitherto only been recorded in South Africa on the African continent (Adam et al. 1996). Because of the worldwide distribution and the emergence of tospoviruses as major constraints to crop production, the identification of GRSV in groundnut in Ghana highlights the need for its inclusion in future groundnutbreeding programs. Reports of damage by GRSV underscore the need for further epidemiological studies and the development of appropriate control measures. Management strategies for both viral diseases should include practices that aim to reduce inoculum sources to prevent tolerant or resistant varieties from succumbing to the disease at high inoculum pressures.

\section{Acknowledgments}

We thank Australian Aid for International Development for the Australian Development Scholarship to A. S. Appiah; and the Tasmanian Institute of Agriculture, Biotechnology, and Nuclear Agriculture Research Institute and the Radiological and Medical Science Research Institute of the Ghana Atomic Energy Commission for the use of their facilities.

\section{Literature Cited}

Adam, G., Peters, D., and Goldbach, R. W. 1996. Serological comparison of Tospovirus isolates using polyclonal and monoclonal antibodies. Acta Hortic. 431:135-158.
Adu-Dapaah, H. K., Asibuo, J. Y., Danquah, O. A., Asumadu, H., Haleegoah, J. and Agyei, B. A. 2004. Farmer Participation in Groundnut Rosette Resistan Varietal Selection in Ghana. Research Report. Crops Research Institute, Kumasi, Ghana.

Anonymous. 1996. SADC/ICRIST Groundnut Project Annual Progress Report for 1996. Chitdze Research Station, Lilongwe, Malawi.

Boari, A. J., Maciel-Zambolim, E., Lau, D. D., Lima, G. S. A., Kitajima, E. W. Brommonschenkel, S. H., and Zerbini, F. M. 2002. Detection and partial characterization of an isolate of Groundnut ringspot virus in Solanum sessiliflorum. Fitopatol. Bras. 27:249-253.

Bock, K., Murant, A., and Rajeshwari, R. 1990. The nature of the resistance in groundnut to rosette disease. Ann. Appl. Biol. 117:379-384.

Bock, K. R., and Nigam, S. N. 1988. Methodology of groundnut rosette screening and vector-ecology studies in Malawi. Pages 6-10 in: Coordinated research on groundnut rosette virus disease. D. McDonald, D. V. R. Reddy, J. A Wightman, and S. N. Nigam, eds. International Crops Research Institute for the Semi-Arid Tropics. (ICRISAT), Andhra Pradesh, India.

Camelo-García, V. M., Lima, E. F. B., Mansilla-Córdova, P. J., Rezende, J. A. M., Kitajima, E. W., and Barreto, M. 2014. Occurrence of Groundnut ringspot virus on Brazilian peanut crops. J. Gen. Plant Pathol. 80:282-286.

Catherinet, M., Sauger, L., and Durand, Y. 1954. Contribution a 1'etude de la rosette chlorotique de l'arachide. Bull. Agron. Ministere France Outremer 13: 163-180.

Chiyembekeza, A. J., Subrahmanyam, P., and Hildebrand, G. L. 1997. Identification and farm evaluation of rosette-resistant groundnut genotypes in Malawi. Pages 20-21 in: Groundnut Virus Diseases in Africa: Summary and Recommendations, 6th Meet. Int. Working Group. D. V. R. Reddy, P. Delfosse, J. M. Lenne, and P. Subrahmanyam, eds. Agricultural Research Council, Plant protection Research Institute, Pretoria, South Africa; International Crops Research Institute for the Semi-Arid Tropics, Andhra Pradesh, India; and Belgian Administration for Development Co-operation, Belgium.

de Ávila, A. C., de Haan, P., Kormelink, R., Resende, R. O., Goldbach, R. W., and Peters, D. 1993. Classification of tospoviruses based on phylogeny of nucleoprotein gene sequences. J. Gen. Virol. 74:153-159.

de Breuil, S., Abad, J. A., Nome, C. F., Giolitti, F. J., Lambertini, P. L., and Lenardon, S. 2007. Groundnut ringspot virus: An emerging tospovirus inducing disease in peanut crops. J. Phytopathol. 155:251-254.

Funayama, S., Sonoike, K., and Terashima, I. 1997. Photosynthetic properties of leaves of Eupatorium makinoi infected by a geminivirus. Photosynth. Res. 53:253-261.

Gibbons, R. W. 1977. Groundnut rosette virus. Pages 19-21 in: Diseases of Tropical Crops. J. Kranz, J. Schutter, and W. Koch, eds. Verlag Paul Parey,Berlin.

Gibbs, A. J., and Gower, J. C. 1960. The use of multiple-transfer method in plant virus transmission studies-some statistical points arising in the analysis of results. Ann. Appl. Biol. 48:75-83.

Herselman, L., Thwaites, R., Kimmins, F. M., Courtois, B., van der Merwe, P. J. A., and Seal, S. E. 2004. Identification and mapping of AFLP markers linked to peanut (Arachis hypogaea L.) resistance to the aphid vector of groundnut rosette disease. Theor. Appl. Genet. 109:1426-1433.

Kabbia, M. K. 2013. Studies on the inheritance of seed quality traits in groundnut (Arachis hypogaea L.) M. Sc. thesis, Kwame Nkrumah University of Science and Technology, Kumasi, Ghana.

Leão, E. U., Spadotti, D. M. A., Rocha, K. C. G., Pantoja, K. F. C., Rezende, J. A. M., Pavan, M. A., and Krause-Sakate, R. 2014. Citrullus lanatus is a new natural host of Groundnut ringspot virus in Brazil. J. Phytopathol. 163:1014-1018.

Minja, E. M., van der Merwe, P. J. A., Kimmins, F. M., and Subrahmanyam, P. 1999. Screening groundnut breeding lines for resistance to aphids, Aphid craccivora Koch. Int. Arachis Newsl. 19:21-23.

Murant, A. F., and Kumar, I. K. 1990. Different variants of the satellite RNA of groundnut rosette virus are responsible for the chlorotic and green forms of groundnut rosette diseases. Ann. Appl. Biol. 117:85-92.

Naidu, R. A., Bottenberg, H., Subrahmanyam, P., Kimmins, F. M., Robinson, D. J., and Thresh, J. M. 1998. Epidemiology of groundnut rosette virus disease: Current status and future research needs. Ann. Appl. Biol. 132:525-548.

Naidu, R. A., and Kimmins, F. M. 2007. The effect of Groundnut rosette assistor virus on the agronomic performance of four groundnut (Arachis hypogaea L.) genotypes. J. Phytopathol. 155:350-356.

Naidu, R. A., Kimmins, F. M., Deom, C. M., Subrahmanyam, P., Chiyembekeza, A. J., and van de Merwe, P. J. A. 1999a. Groundnut rosette: A virus disease affecting groundnut production in sub- Saharan Africa. Plant Dis. 83:700-709.

Naidu, R. A., Kimmins, F. M., Holt, J., Robinson, D. J., Deom, C. M., and Subrahmanyam, P. 1999b. Spatiotemporal separation of groundnut rosette disease agents. Phytopathology 89:934-941.

Ntare, B. R., and Olorunju, P. E. 2001. Variation in yield and resistance to groundnut rosette disease in early- and medium-maturing groundnut genotypes in Nigeria. Afr. Crop Sci. J. 9:451-461.

Okusanya, B. A. M., and Watson, M. A. 1966. Host range and some properties of groundnut rosette virus. Ann. Appl. Biol. 58:377-87.

Olorunju, P. E., Kuhn, C. W., Demski, K. W., Misari, S. M., and Ansa, O. A 1991. Disease reactions and yield performance of peanut genotypes grown under groundnut rosette and rosette-free field environments. Plant Dis. 75 $1269-1273$ 
Olorunju, P. E., Ntare, B. R., Pande, S., and Reddy, S. V. 2001. Additional sources of resistance to groundnut rosette disease in groundnut germplasm and breeding lines. Ann. Appl. Biol. 139:259-268.

Owusu-Akyaw, M., Mochiah, M. B., Gyasi-Boakye, S., and Asafu-Agyei, J. N. 2014. Integrated Practices to Manage Diseases, Nematodes, Weeds and Arthropod Pests of Groundnut in Ghana. Council for Scientific and Industrial Research-Crops Research Institute, Kumasi, Ghana, and North Carolina State University, Raleigh, NC

Pappu, H., Jones, R., and Jain, R. 2009. Global status of Tospovirus epidemics in diverse cropping systems: Successes achieved and challenges ahead. Virus Res. 141:219-236.

Pietersen, G., and Morris, J. 2002. Natural Occurrence of Groundnut ringspot virus on Soybean in South Africa. Plant Dis. 86:1271.

Rajeshwari, R., Murant, A. F., and Massalski, P. R. 1987. Use of monoclonal antibody to potato leafroll virus for detecting groundnut rosette assistor virus by ELISA. Ann. Appl. Biol. 111:353-358.

Singh, V., and Shukla, K. 2009. Effect of PRSV infection on pigment content and assimilation of carbohydrate in Carica papaya L. Ann. Plant Prot. Sci. 17: 152-156.

Spadotti, D. M. A., Leão, E. U., Rocha, K. C. G., Pavan, M. A., and Krause-Sakate, R. 2014. First report of Groundnut ringspot virus in cucumber fruits in Brazil. New Dis. Rep. 29:25.

Storey, H. H., and Ryland, A. K. 1957. Viruses causing rosette and other diseases in groundnuts. Ann. Appl. Biol. 45:318-326.

Subrahmanyam, P., Hildebrand, G. L., Naidu, R. A., Reddy, L. J., and Singh, A. K. 1998. Sources of resistance to groundnut rosette disease in global groundnut germplasm. Ann. Appl. Biol. 132:473-485.
Subrahmanyam, P., van Wyk, P. S., Kisyombe, C. T., Cole, D. L., Hildebrand, G. L., Chiyembekeza, A. J., and van der Merwe, P. J. A. 1997. Diseases of groundnut in the Southern African Development Community Region and their management. Int. J. Pest Manage. 43:261-273.

Sutha, R. M. R., and Rajappan, K. 1998. Effect of tomato spotted wilt virus infection on photosynthetic pigments in tomato. Plant Dis. Res. 13:138-140.

Tengey, T. K., Kena, A. W., Kwoseh, C., and Akromah, R. 2013. Evidence for the production and accumulation of phytoalexins in the cotyledons of selected legumes following treatments with biotic elicitors. Int. J. Plant Pathol. 4:9-22.

Waliyar, F., Kumar, P. L., Ntare, B. R., Monyo, E., Nigam, S. N., Reddy, A. S., Osiru, M., and Diallo, A. T. 2007. A century of research on groundnut rosette disease and its management. Inf. Bull. No. 75. International Crops Research Institute for the Semi-Arid Tropics, Andhra Pradesh, India.

Webster, C. G., Frantz, G., Reitz, S. R., Funderburk, J. E., Mellinger, H. C., McAvoy, E., Turechek, W. W., Marshall, S. H., Tantiwanich, Y., McGrath, M. T., Daughtrey, M. L., and Adkins, S. 2015. Emergence of Groundnut ringspot virus and Tomato chlorotic spot virus in vegetables in Florida and the Southeastern United States. Phytopathology 105:388-398.

Webster, C. G., Perry, K. L., Lu, X., Horsman, L., Frantz, G., Mellinger, C., and Adkins, S. 2010. First report of Groundnut ringspot virus infecting tomato in south Florida Online publication. Plant Health Prog. doi:10.1094/PHP-2010-0707-01-BR

Wilson, C. R. 2014. Applied Plant Virology. CABI Press, Wallingford, UK.

Wynne, J. C., Beute, M. K., and Nigam, S. N. 1991. Breeding for disease resistance in peanut (Arachis hypogaea L.). Annu. Rev. Phytopathol. 29:279-303.

Yayock, J. Y., Rossel, H. W., and Harkness, C. 1976. A review of the 1975 groundnut rosette epidemic in Nigeria. Inst. Agric. Res. Samaru Conf. Pap. No. 9. Institute of Agricultural Research, Samaru. 